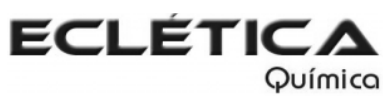

www.scielo.br/eq

www.ecletica.iq.unesp.br

Volume 33, número 2, 2008

\title{
Study of complexes of cadmium with some L-amino acids and vitamin- $C$ by voltammetric technique
}

\author{
F. Khan* and A. Khanam \\ Electrochemical Laboratory, Department of Chemistry \\ Dr. H. S. Gour University, Sagar - 470003 (M.P.) India \\ *faridkhan58@yahoo.com; farid.fk@rediffmail.com
}

\begin{abstract}
Voltammetric technique was used to study the binary and ternary complexes of cadmium with $\mathrm{L}$-amino acids and vitamin-C (L-ascorbic acid) at $\mathrm{pH}=7.30 \pm 0.01, \mu=1.0 \mathrm{M} \mathrm{KNO} \mathrm{KN}_{3}$ at $25^{\circ} \mathrm{C}$ and $35^{\circ} \mathrm{C}$. Cd (II) formed 1:1:1, 1:1:2 and 1:2:1 complexes with L-lysine, L-ornithine, L-threonine, L-serine, L-phenylglycine, L-phenylalanine, L-glutamic acid and L-aspartic acid used as primary ligands and L-ascorbic acid used as secondary ligand. The trend of stability constant of complexes was Llysine $<$ L-ornithine $<$ L-threonine $<$ L-serine $<$ L-phenylglycine $<$ L-phenylalanine $<$ L-glutamic acid $<\mathrm{L}$-aspartic acid which can be explained on the basis of size, basicity and steric hindrance of ligands. The values of stability constant $(\log \beta)$ varied from 2.23 to11.33 confirm that these drugs i.e. L-amino acids or in combination with L-ascorbic acid or their complexes could be used against Cd (II) toxicity. The study has been carried out at $35^{\circ} \mathrm{C}$ also to determine the thermodynamic parameters such as enthalpy change $(\Delta \mathrm{H})$, Free energy change $(\Delta \mathrm{G})$ and entropy change $(\Delta \mathrm{S})$ respectively.
\end{abstract}

Keywords: voltammetry; thermodynamic parameters; vitamin-C; Cd (II) complexes.

\section{Introduction}

The L-amino acids and their compounds are used in biology, pharmacy, industry and laboratory reagents [1-3]. They also control transamination, decarboxylation and metabolism processes in human body. On the other hand, L-ascorbic acid (vitamin-C) is an important drug used against cancer, scurvy and reduced the risk of bronchitis or wheezing [4-6]. It is also an important drug to help the patient to increase the immune system. The person who suffered from AIDS has low concentration of vitamin-C. Vitamin-C is also responsible for the functions of various body components and organs but also keeps in order the immune system [7, 8]. The deficiency of vitamin-C causes anemia, dental cavities and thyroid insufficiency.

Cd (II) is the one of the toxic metal in the environment to which industrial civilization has exposed itself [9]. Cd (II) contents is fixed in human body but whenever the concentration of $\mathrm{Cd}$ increases, the human being suffers from several severe diseases like cancer of the bladder, breast, intestine, leukemic system and sometimes death can also occur. Till now, there is no suitable antidote available for $\mathrm{Cd}$ toxicity. At present, $\mathrm{H}_{4}$ EDTA and its derivatives are used for $\mathrm{Cd}$ intoxication. Initially they reduce the toxicity of $\mathrm{Cd}$ (II) but eventually increase the nephrotoxicity therefore; the uses of these drugs against Cd (II) toxicity are questionable [10]. The present study is related with 
the formation of binary and ternary complexes of Cd (II) with selected L- amino acids and ascorbic acid by voltammetric technique with the view that these drugs or their metal complexes could be used against several severe diseases like cancer, AIDS and also metal toxicity.

\section{Experimental}

The following chemicals were used for all polarographic experiments: $\mathrm{HNO}_{3}$ (Sigma), $\mathrm{NaOH}$ (Sigma), $\mathrm{KNO}_{3}$ (Fluka), gelatin (B.D.H.), $\mathrm{Cd}\left(\mathrm{NO}_{3}\right)_{2} \cdot 4 \mathrm{H}_{2} \mathrm{O}$ (B.D.H.), L-amino acids (Lobachem) and vitamin-C (ascorbic acid) (Fluka) and their solutions were prepared in double distilled water. The purity of L-amino acids was checked by Chromatography method [11]. The concentration of metal, $\mathrm{KNO}_{3}$ and gelatin in test solution was 0.5 $\mathrm{mM}, 1.0 \mathrm{M}$ and $0.001 \%$ respectively.

The depolarizer and ligands (i.e. amino acid and vitamin-C) were taken in the ratio 1:30:30 in the case of ternary complexes and current - voltage curves were obtained at different $\mathrm{pH}$ values. It has been observed that the maximum shift of $E_{1 / 2}$ was obtained within the $\mathrm{pH}$ range $7.10-8.50$ but $\mathrm{pH} 7.30$ was selected for studying the complexes in human blood $\mathrm{pH}$ $[12,13]$.

Electrochemical experiments were made by simple DC polarography carried out on a manual polarograph using a (Toshniwal PL-50) polyflex galvanometer. The polarographic cell was of Laitinen and Lingane type in which polarographic capillary of $5.0 \mathrm{~cm}$ in length with $0.04 \mathrm{~mm}$ in diameter was used. The $\mathrm{m}^{2 / 3} \mathrm{t}^{1 / 6}$ value was $2.40 \mathrm{mg}^{2 / 3} \mathrm{~s}^{-1 / 2}$ at $60.02 \mathrm{~cm}$ effective height of mercury. A systronic $\mathrm{pH}$ meter 361 was used to measure the $\mathrm{pH}$ of the analyte at $7.30 \pm 0.01$ adjusted by using dilute solutions of $\mathrm{HNO}_{3}$ or $\mathrm{NaOH}$ as required. Potassium dihydrogen phosphate-sodium hydroxide buffer was added to stabilize the $\mathrm{pH}$ of the analyte.

Electrochemical measurement was performed in the solutions of physiological ionic strength $(1.0 \mathrm{M}) \mathrm{KNO}_{3}$ as the supporting electrolyte while $0.001 \%$ gelatin was the maxima suppressor. The entire study was carried out at $298 \mathrm{~K}$ and $308 \mathrm{~K}$.

\section{Result and discussion}

Electrochemical investigation of $\mathrm{Cd}$ (II) complexes with L-amino acids and vitamin-C (Lascorbic acid) was performed using simple polarography. Cd (II) gives a well defined two electron reversible reduction and diffusion controlled wave in $1.0 \mathrm{M} \mathrm{KNO}_{3}$ at $\mathrm{pH}=7.3 \pm 0.010$ at $25^{\circ} \mathrm{C}[14,15]$. The metal ion and ligands were taken in the ratio 1:30 in binary complexes and 1:30:30 in case of ternary complexes and polarograms were taken at different $\mathrm{pH}$ values, it has been observed that the maximum shift of $\mathrm{E}_{1 / 2}$ was obtained at $\mathrm{pH}$ range $7.10-8.50$ but $\mathrm{pH} 7.30$ was selected for studying the complexes in human blood $\mathrm{pH}$. All the waves of the complexes were reversible and diffusion controlled as clear from the plots between $E_{\text {d.e. }}$ vs. $\log \left(i_{d}-i\right) / i$ and $i_{d}$ vs $\sqrt{ } \mathrm{h}$ respectively [16].

\section{Binary complexes}

[Cd - L - amino acidate] system: The $\mathrm{pK}$ values of amino acids were determined by titration method [17]. The concentration of the free ligand was calculated from $\mathrm{pK}_{2}$ value and $\mathrm{pH}$ of test solution. Deford and Hume [18] was used to determine the composition and stability constants of binary complexes of $\mathrm{Cd}(\mathrm{II})$ with L-lysine, Lornithine, L-threonine, L-serine, L-phenylglycine, L-phenylalanine, L-glutamic acid and Laspartic acid. The values of stability constants of binary complexes were given in Table 1 . The study has already been done at $\mathrm{pH}=8.50$ [19], however the present study has been done at $\mathrm{pH}=$ 7.30 to compare the values of stability constants.

[Cd- vitamin-C] complexes: The concentration of vitamin-C (L-ascorbic acid) in the analyte was varied from $50 \mathrm{mM}$ to $200 \mathrm{mM}$ in 0.5 $\mathrm{mM}$ of $\mathrm{Cd}$ (II) in $1.0 \mathrm{M} \mathrm{KNO}_{3}$ at $\mathrm{pH}=7.30 \pm 0.01$ at $25^{\circ} \mathrm{C}$. Lingane method [20] confirmed the formation of $1: 1$ and 1:2 complexes of $\mathrm{Cd}$ (II) with vitamin-C with stability constants $\log \beta_{01}=2.23$ and $\log \beta_{02}=3.11$ respectively.

\section{Ternary Complexes}

[Cd - L-amino acidate - vitamin-C] complexes: The $E_{1 / 2}$ values became more negative with addition of vitamin-C to [Cd-L-amino acidate] [18] system at $\mu=1.0 \mathrm{M} \mathrm{KNO}_{3}$ and $\mathrm{pH}=7.30 \pm 0.01$ show- 
ing the formation of ternary complexes. The concentrations of the secondary ligand were kept constant at $0.025 \mathrm{M}$ and $0.05 \mathrm{M}$ while the concentration of primary ligand was varied from $0.50 \mathrm{mM}$ to 30.0 $\mathrm{mM}$. The current voltage curves were drawn at $\mathrm{pH}=7.30 \pm 0.010$. All the waves were found to be reversible and diffusion controlled. The Schaap and McMaster [21] method confirmed the formation of 1:1:1, 1:1:2 and 1:2:1 complexes of Cd (II) with L- lysine, L-ornithine, L-threonine, L-serine, Lphenylglycine, L-phenylalanine, L-glutamic acid and L-aspartic acid and vitamin-C. The data and plots of $\mathrm{F}_{\mathrm{ij}}[\mathrm{X}, \mathrm{Y}]$ against $[\mathrm{X}]$ (where $\mathrm{F}_{\mathrm{ij}}$ is a Schaap and McMaster Function to evaluate the stability constant $\beta_{\mathrm{ij}}, \mathrm{X}=\mathrm{L}-\mathrm{lysine}, \mathrm{Y}=$ vitamin- $\mathrm{C}$ and $\mathrm{i}$ and $\mathrm{j}$ are their stoichiometric numbers respectively\} for [Cd-L-lysinate-vitamin-C] system were given in Table 2 and Fig. 1 respectively. These functions

Table 1. Stability constants of ternary complexes, Metal ion $\mathrm{Cd}(\mathrm{II})=0.5 \mathrm{mM} ; \mu=1.0 \mathrm{M} ; \mathrm{pH}=7.3 \pm 0.01$; Temperature $=25^{\circ} \mathrm{C}$.

\begin{tabular}{|c|c|c|c|c|c|c|c|c|c|}
\hline Primary Ligand & $\log \beta_{01}$ & $\log \beta_{02}$ & $\log \beta_{03}$ & $\log \beta_{10}$ & $\log \beta_{20}$ & $\log \beta_{30}$ & $\log \beta_{11}$ & $\log \beta_{12}$ & $\log \beta_{21}$ \\
\hline L-lysine & - & - & - & $(3.70)^{18}, 3.65$ & $(6.48)^{18}, 6.37$ & $(9.24)^{18}, 9.19$ & 4.45 & - & 10.22 \\
\hline L-ornithine & - & - & - & (3.77), 3.70 & $(6.61), 6.45$ & $(9.42), 9.37$ & 4.61 & 7.52 & 10.42 \\
\hline L-threonine & - & - & - & $(4.00), 3.72$ & $(7.00), 6.67$ & $(9.50), 9.42$ & 4.95 & 7.64 & 10.53 \\
\hline L-serine & - & - & - & $(4.07), 3.90$ & $(7.13), 7.00$ & $(9.69), 9.50$ & 5.11 & 7.86 & 10.75 \\
\hline L-phenylglycine & - & - & - & $(4.10), 4.00$ & (7.24), 7.15 & $(9.71),-$ & 5.21 & 7.95 & 10.83 \\
\hline L-phenylalanine & - & - & - & $(4.17), 4.10$ & (7.37), 7.25 & $(9.90), 9.82$ & 5.37 & 8.17 & 11.05 \\
\hline L-glutamic acid & - & - & - & $(4.30), 4.25$ & $(7.45), 7.38$ & $(10.00), 10.00$ & 5.56 & - & 11.11 \\
\hline L-aspartic acid & - & - & - & $(4.37), 4.30$ & $(7.58), 7.56$ & $(10.24), 10.18$ & 5.72 & 8.23 & 11.33 \\
\hline $\begin{array}{l}\text { Vitamin-C } \\
\text { (ascorbic acid) }\end{array}$ & 2.23 & 3.11 & 3.75 & & & & & & \\
\hline
\end{tabular}

(The values under bracket shows the values of stability constants calculated at $\mathrm{pH}=8.50$.)

Table 2. Polarographic data and Fij[X, Y $]$ values of $[\mathrm{Cd}-\mathrm{L}-$ lysinate - vitamin-C $]$ system, $\mathrm{Cd}(\mathrm{II})=0.50 \mathrm{mM}$, $\mu=1.0 \mathrm{M} \mathrm{KNO} 3, \mathrm{pH}=7.30 \pm 0.01$, Temp. $=25^{\circ} \mathrm{C}$.

\begin{tabular}{|c|c|c|c|c|c|c|c|c|c|c|c|c|}
\hline \multirow{2}{*}{$\begin{array}{l}\text { [L-lys] } \\
\mathrm{X} 10^{3} \mathrm{M}\end{array}$} & \multicolumn{6}{|c|}{$[$ vitamin-C] $=0.025 \mathrm{M}$ (Fixed) } & \multicolumn{6}{|c|}{$[$ vitamin-C] $=0.050 \mathrm{M}$ (Fixed) } \\
\hline & $\begin{array}{l}E_{1 / 2}^{r}-V \\
\text { vs SCE }\end{array}$ & $\log \mathbf{i}_{\mathrm{m}} / \mathbf{i}_{\mathrm{c}}$ & $\mathrm{F}_{00}[\mathrm{X}, \mathrm{Y}]$ & $\begin{array}{l}\mathrm{F}_{10}[\mathrm{X}, \mathrm{Y}] \\
\mathrm{X} 10^{4}\end{array}$ & $\begin{array}{l}\mathrm{F}_{20}[\mathrm{X}, \mathrm{Y}] \\
\mathrm{X} 10^{7}\end{array}$ & $\begin{array}{l}\mathrm{F}_{30}[\mathrm{X}, \mathrm{Y}] \\
\mathrm{X} 10^{7}\end{array}$ & $\begin{array}{l}E_{1 / 2}{ }^{r}-V \\
\text { vs } \quad \text { SCE }\end{array}$ & $\log i_{m} / i_{c}$ & $\mathrm{~F}_{00}[\mathrm{X}, \mathrm{Y}]$ & $\begin{array}{l}\mathrm{F}_{10}[\mathrm{X}, \mathrm{Y}] \\
\mathrm{X} 10^{3}\end{array}$ & $\begin{array}{l}\mathrm{F}_{20}[\mathrm{X}, \mathrm{Y}] \\
\mathrm{X} 10^{5}\end{array}$ & $\begin{array}{l}\mathrm{F}_{30}[\mathrm{X}, \mathrm{Y}] \\
\mathrm{X} 10^{6}\end{array}$ \\
\hline 0.50 & 0.6460 & 0.0219 & 114.17 & 21.60 & 42.07 & 173.78 & 0.6545 & 0.0219 & 225.99 & 42.51 & 83.74 & 173.78 \\
\hline 1.00 & 0.6630 & 0.0295 & 433.42 & 42.72 & 42.16 & 173.77 & 0.6715 & 0.0295 & 858.17 & 84.47 & 83.83 & 173.77 \\
\hline 2.00 & 0.6800 & 0.0371 & 1710.79 & 85.23 & 42.33 & 173.76 & 0.6890 & 0.0371 & 3386.62 & 168.66 & 84.00 & 173.76 \\
\hline 3.00 & 0.6905 & 0.0449 & 3848.66 & 128.08 & 42.50 & 173.75 & 0.6990 & 0.0449 & 7609.14 & 253.19 & 84.18 & 173.79 \\
\hline 4.00 & 0.6975 & 0.0529 & 6857.50 & 171.28 & 42.67 & 173.74 & 0.7065 & 0.0449 & 13536.16 & 338.06 & 84.35 & 173.78 \\
\hline 5.00 & 0.7030 & 0.0611 & 10745.0 & 214.77 & 42.85 & 173.75 & 0.7120 & 0.0529 & 21178.12 & 423.29 & 84.53 & 173.77 \\
\hline 6.00 & 0.7075 & 0.0693 & 15529.74 & 258.73 & 43.03 & 173.78 & 0.7165 & 0.0529 & 30545.45 & 508.86 & 84.70 & 173.77 \\
\hline 8.00 & 0.7150 & 0.0777 & 27810.80 & 347.56 & 43.37 & 173.77 & 0.7240 & 0.0693 & 54497.83 & 681.05 & 85.05 & 173.76 \\
\hline 10.00 & 0.7205 & 0.0777 & 43784.07 & 437.78 & 43.72 & 173.76 & 0.7295 & 0.0693 & 85476.88 & 854.63 & 85.39 & 173.77 \\
\hline 20.00 & 0.7385 & 0.0864 & 181955.57 & 909.75 & 45.46 & 173.78 & 0.7470 & 0.0777 & 348690.47 & 1743.38 & 87.13 & 173.78 \\
\hline 30.00 & 0.7495 & 0.0864 & 424946.81 & 1416.47 & 47.19 & 173.78 & 0.7575 & 0.0864 & 800080.67 & 2666.89 & 88.87 & 173.78 \\
\hline
\end{tabular}



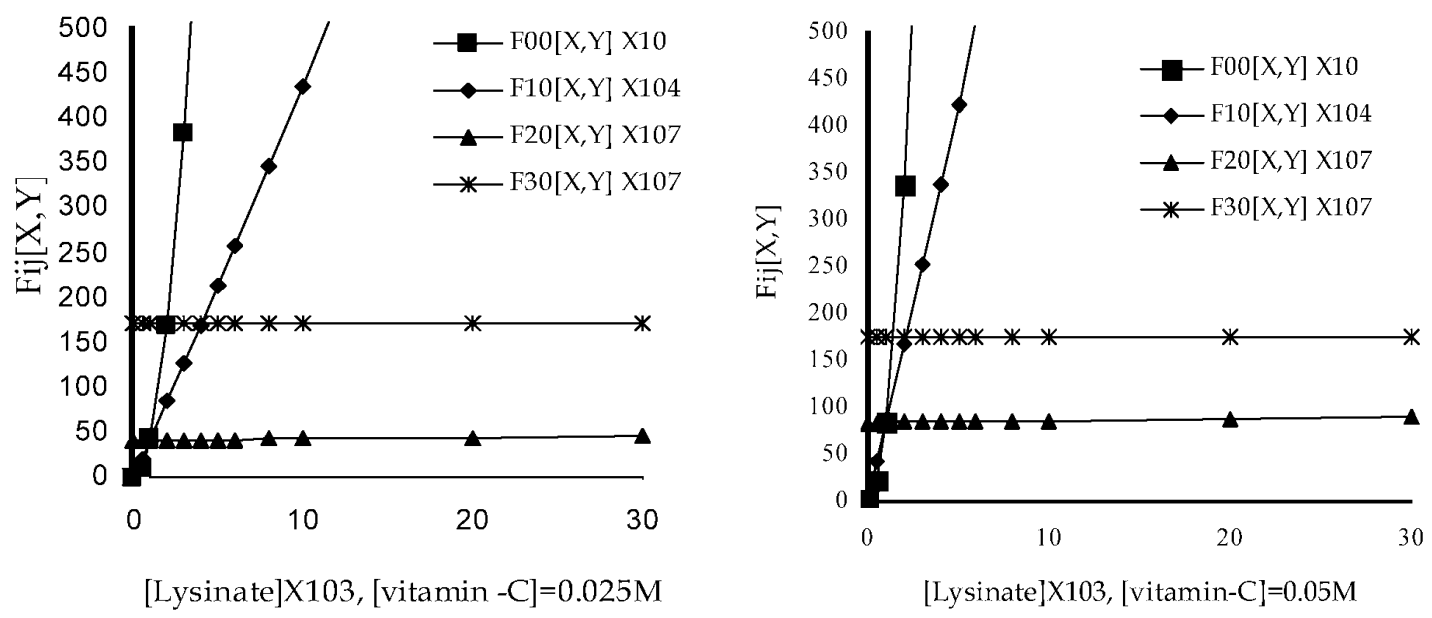

Figure 1. Plot of Fij[X, Y] vs. [X] for [Cd (II)-L-lysinate-vitamin-C] system.

were used to determine the stability constant of complexes.

To know the values of $\beta_{11}$ and $\beta_{12}$, the study has been carried out at two constant concentration of secondary ligand $[\mathrm{Y}]=[$ vitamin-C $]$ at $0.025 \mathrm{M}$ and $0.05 \mathrm{M}$ respectively. The value of stability constants of complexes were given in Table 1 . The current voltage curves of [Cd-L-lysinate-vitamin-C] at [vitamin-C] $=0.025 \mathrm{M}$ were given in Fig. 2 and Fig. 3 showed the polarographic experimental set up to study the interaction of Cd (II) with some Lamino acids and vitamin-C.

Comparison of stability of binary and ternary complexes

To compare the stability of binary and ternary complexes, the values of mixing constant $\log \mathrm{Km}$ were calculated by the following equation [21].

$$
\log \mathrm{Km}=\log \beta_{11}-1 / 2\left[\log \beta_{02}+\log \beta_{20}\right]
$$

The values of $\log \mathrm{Km}$ are $-0.345,-0.250$, $-0.105,-0.010,0.035,0.130,0.280,0.375$ respectively, for $\{\mathrm{Cd}-\mathrm{L}-\mathrm{lysinate}-\mathrm{vitamin}-$ C $\},\{\mathrm{Cd}$-L-ornithinate-vitaminC $\},\{\mathrm{Cd}-\mathrm{L}-$ threoninate-vitamin-C $\},\{\mathrm{Cd}-\mathrm{L}-$ serinate-vitamin-C, $\{\mathrm{Cd}$-L-phenylglycinate-vitamin-C $\},\{\mathrm{Cd}-\mathrm{L}-$ phe nylalaninate-vitamin-C $\},\{\mathrm{Cd}-\mathrm{L}-$ glutamate-vitamin- $\},\{$ Cd-L-aspartate-vitamin-C $\}$ complexes respectively. The positive values of $\log \mathrm{Km}$ indicate that the ternary complexes are more stable than the binary complexes, while the negative values indicate that the binary complexes are more stable than ternary complexes.

Trend of stability constants of Cd (II) complexes

The sequence of stability constants of complexes with respect to ligands is L-lys $<\mathrm{L}$ orn $<$ L-thr $<$ L-ser $<$ L-phg $<$ L-phe $<$ L-glu $<$ Lasp. It has been observed that as the size of amino acids increased the stability of its complexes decreased [22]. The stability of L-amino acid complex also depends upon the chelate ring formation and basicities of ligands [23]. In this study, the stability of lysinate complex is minimum owing to the lowest $\mathrm{pK}$ value of L-lysine as expected [24]. In case of L-serine and L-threonine, the stability of the latter is less than the Lserine complex owing to the fact that electron withdrawing $\mathrm{OH}^{-}$group is nearer to L-threoninate complex than L-serinate complex, causing greater repulsive forces between metal and $\mathrm{OH}^{-}$ group in L-threonine complexes than L-serine complexes [25]. In case of L-phenylglycine and L- phenylalanine, the order of stability is reversed i.e. L-phenylglycine < L-phenylalanine, this could be attributed to the presence of phenyl group lying at $\alpha$-carbon atom in L-phenylglycine, whereas it is at $\beta$-carbon atom in case of $\mathrm{L}$ - 
[L-Lys inate $]=0.00 \mathrm{M}$

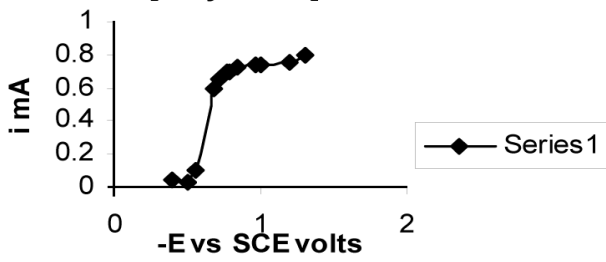

[L- Lys inate] $=0.0005 \mathrm{M}$
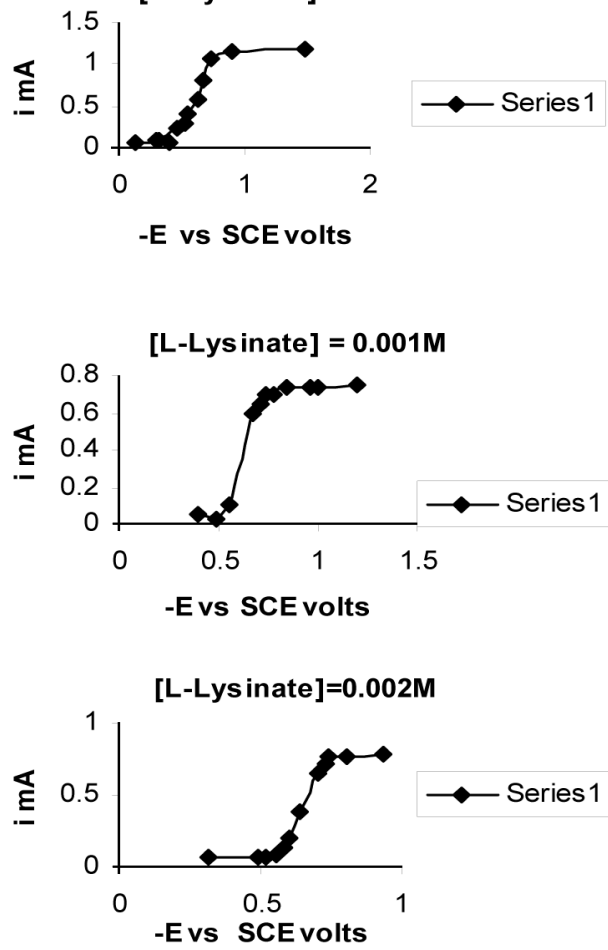

[L-Lys inate] $=0.003 \mathrm{M}$
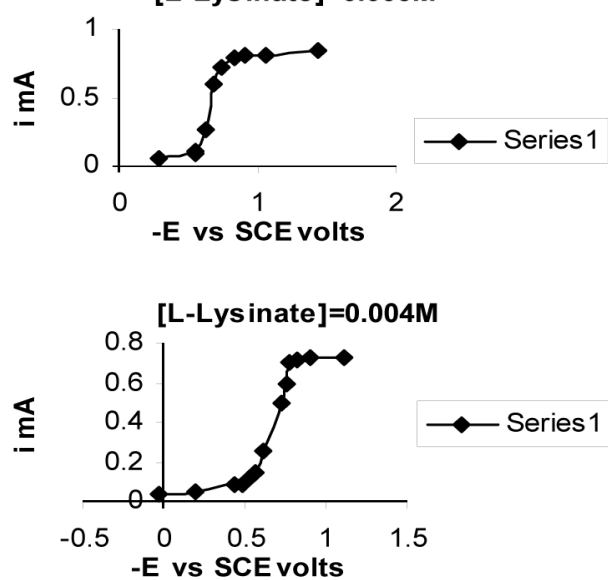

[L-Lys inate] $=0.005 \mathrm{M}$

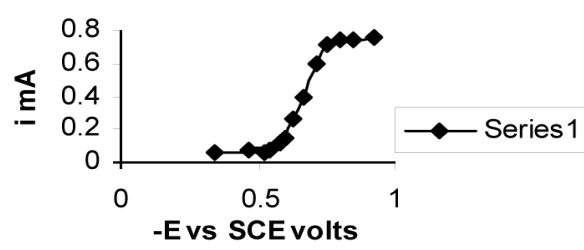

[L-Lys inate] $=0.006 \mathrm{M}$

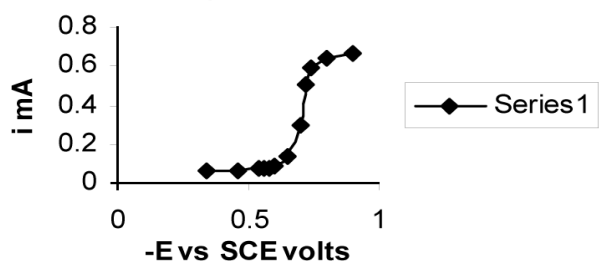

[L- Lys inate] $=0.008 \mathrm{M}$
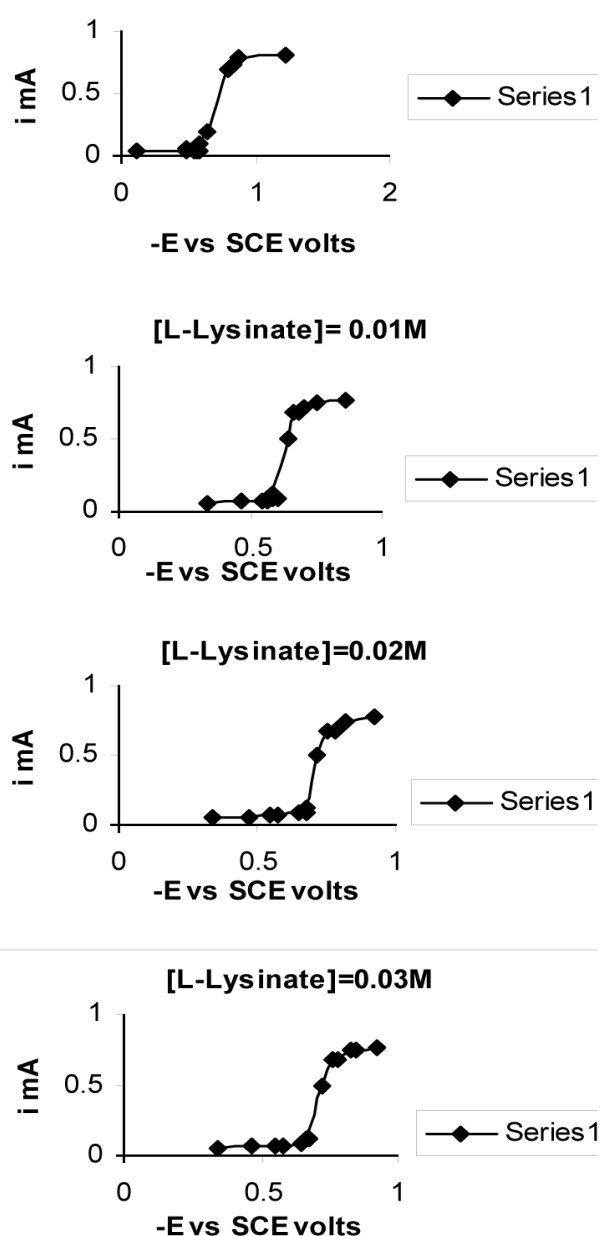

Figure 2. [Cd - L- lysinate - vitamin-C] system, [vitamin-C] $=0.025 \mathrm{M}$. 


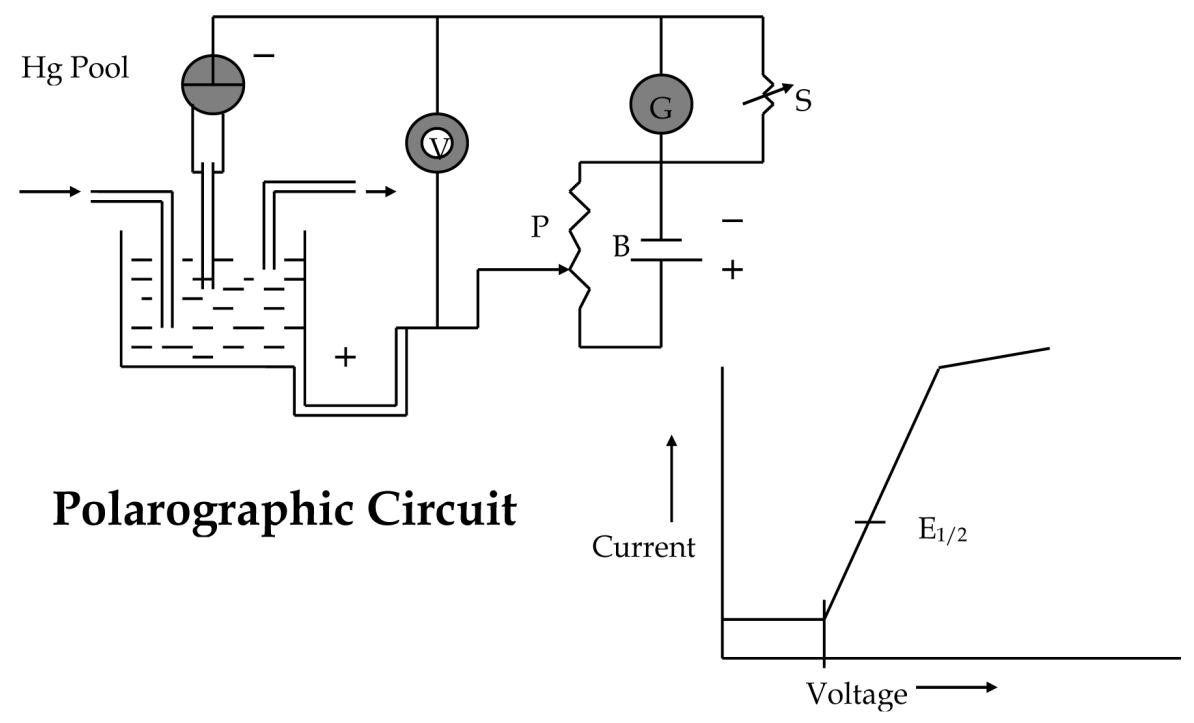

Current - Voltage Curve

Figure 3. Polarographic set up.

phenylalanine causing greater repulsive forces in the former than in the latter.

The higher stability of L-aspartate complexes than L-glutamate complex is obvious from the chelate ring formation, in these amino acids, the aspartate forms one five and one sixmembered ring with the metal while L-glutamate forming one five and one seven-membered ring. As the size of ring in amino acid increases, the stability of complex decreases [26]. The stabilities of L-glutamate and L-aspartate complexes are greater than those of the L-lysinate, Lornithinate, L-threoninate, L-serinate, L-phenylglycinate and phenylalaninate complexes due to large difference in their basic strength [27]. The same is evident from $\mathrm{pK}$ values of L-aminoacids [28].

In case of vitamin- $\mathrm{C}$, oxygen of enediol group may take part in bond formation with $\mathrm{Cd}^{\mathrm{II}}$, formed a five membered ring [29].

It is clear from the values of stability constant of the complexes that vitamin-C and L-amino acids alone or in combination could be used to reduce the toxicity of CdII in vivo. One also to consider the quantity of drugs that should not be complexed to the other essential metals present in vivo and the same could be excreted easily from the body. On the other hand, the person who suffers from AIDS has low concentration of vitamin-C therefore; his resistance can be increased by ascorbic acid therapy.

\section{Thermodynamic parameters}

The kind of complex species that can be measured with a mercury electrode depends on thermodynamic aspects [30]. Thermodynamic parameters such as enthalpy change $(\Delta \mathrm{H})$, free energy change $(\Delta \mathrm{G})$ and entropy change $(\Delta \mathrm{S})$ of the complexes have been calculated by the following equations [31].

$\Delta \mathrm{H}=2.303 \mathrm{R} \mathrm{T}_{1} \mathrm{~T}_{2}\left(\log \mathrm{K}_{2}-\log \mathrm{K}_{1}\right) / \mathrm{T}_{2}-\mathrm{T}_{1}$

$\Delta \mathrm{G}=-2.303 \mathrm{RT} \log \mathrm{K}$

$\Delta \mathrm{G}=\Delta \mathrm{H}-\mathrm{T} \Delta \mathrm{S}$

It is clear from the values of $\Delta S, \Delta \mathrm{G}$ and $\Delta \mathrm{H}$ in Table 3 that the values of $\Delta \mathrm{S}$ are more negative at higher temperature and $\Delta \mathrm{G}$ are less negative at higher temperature confirmed that complexes are not stable at higher temperature [32, 33]. The negative values of $\Delta \mathrm{H}$ show that reactions are exothermic in nature. 
Table 3. Thermodynamic parameters of ternary complexes of [Cd-L-aminoacidate-vitamin-C] system.

\begin{tabular}{|c|c|c|c|c|c|c|c|c|c|c|c|c|}
\hline \multirow{3}{*}{ System } & \multicolumn{3}{|c|}{ Stability constants } & \multicolumn{3}{|c|}{ - $\Delta$ H K cal./mole } & \multicolumn{3}{|c|}{ - $\Delta \mathbf{G ~ K ~ c a l . / m o l e ~}$} & \multicolumn{3}{|c|}{ - $\Delta$ S K cal./mole } \\
\hline & $\log \beta_{11}$ & $\log \beta_{12}$ & $\log \beta_{21}$ & $\log \beta_{11}$ & $\log \beta_{12}$ & $\log \beta_{21}$ & $\log \beta_{11}$ & $\log \beta_{12}$ & $\log \beta_{21}$ & $\log \beta_{11}$ & $\log \beta_{12}$ & $\log \beta_{21}$ \\
\hline & $\begin{array}{l}25^{\circ} \mathrm{C} / \\
35^{\circ} \mathrm{C}\end{array}$ & $\begin{array}{l}25^{\circ} \mathrm{C} / \\
35^{\circ} \mathrm{C} \\
\end{array}$ & $\begin{array}{r}25^{\circ} \mathrm{C} / \\
35^{\circ} \mathrm{C} \\
\end{array}$ & $\begin{array}{r}\left(35^{\circ}\right. \\
\text { for differ } \\
\end{array}$ & $\begin{array}{l}\left.\mathrm{C}-25^{\circ} \mathrm{C}\right) \\
\text { nce of } 10^{\circ} \mathrm{C}\end{array}$ & & $\begin{array}{l}25^{\circ} \mathrm{C} / \\
35^{\circ} \mathrm{C} \\
\end{array}$ & $\begin{array}{l}25^{\circ} \mathrm{C} / \\
35^{\circ} \mathrm{C} \\
\end{array}$ & $\begin{array}{l}25^{\circ} \mathrm{C} / \\
35^{\circ} \mathrm{C} \\
\end{array}$ & $\begin{array}{l}25^{\circ} \mathrm{C} / \\
3^{\circ} \mathrm{C} \\
\end{array}$ & $\begin{array}{l}25^{\circ} \mathrm{C} / \\
35^{\circ} \mathrm{C} \\
\end{array}$ & $\begin{array}{l}25^{\circ} \mathrm{C} / \\
35^{\circ} \mathrm{C} \\
\end{array}$ \\
\hline \multirow{2}{*}{$\begin{array}{l}\text { [Cd-L-lysinate - } \\
\text { vitamin-C] }\end{array}$} & 4.45 & - & 9.82 & 12.1803 & - & 16.8004 & 6.0683 & - & 13.9366 & 20.5101 & - & 9.6100 \\
\hline & 4.16 & - & 10.42 & & & & 5.8631 & - & 13.8403 & 20.5103 & - & 9.6107 \\
\hline \multirow{2}{*}{$\begin{array}{l}\text { [Cd-L-ornithinate- } \\
\text { vitamin-C] }\end{array}$} & 4.61 & 7.521 & 10.00 & 13.02031 & 13.44032 & 17.6488 & 6.2865 & 10.2561 & 14.2123 & 22.5967 & 10.6853 & 11.5318 \\
\hline & 4.3 & 7.201 & 10.53 & & & & 6.0604 & 10.1491 & 14.0968 & 22.5970 & 10.6858 & 11.5325 \\
\hline \multirow{2}{*}{$\begin{array}{l}\text { [Cd-L-threoni } \\
\text { nate-vitamin-C] }\end{array}$} & 4.95 & 7.637 & 10.12 & 13.0203 & 14.2803 & 17.2204 & 6.7501 & 10.4143 & 14.3607 & 21.0409 & 12.9734 & 9.5963 \\
\hline & 4.64 & 7.297 & 10.75 & & & & 6.5396 & 10.2844 & 14.2645 & 21.0412 & 12.9738 & 9.5969 \\
\hline \multirow{2}{*}{$\begin{array}{l}{[\mathrm{Cd}-\mathrm{L} \text {-serinate - }} \\
\text { vitamin-C] }\end{array}$} & 5.11 & 7.859 & 10.34 & 13.4403 & 14.2803 & 17.2204 & 6.9683 & 10.7173 & 14.6637 & 21.7182 & 11.9565 & 8.5795 \\
\hline & 4.79 & 7.519 & 10.83 & & & & 6.7510 & 10.5975 & 14.5777 & 21.7185 & 11.9571 & 8.5802 \\
\hline \multirow{2}{*}{$\begin{array}{l}{[\mathrm{Cd}-\mathrm{L}-} \\
\text { phenylglycinate } \\
\text {-vitamin-C] }\end{array}$} & 5.21 & 7.95 & 10.39 & 13.0203 & 13.8603 & 18.4804 & 7.1046 & 10.8411 & 14.7698 & 19.8511 & 10.1316 & 12.4518 \\
\hline & 4.9 & 7.62 & 11.05 & & & & 6.9060 & 10.7396 & 14.6451 & 19.8515 & 10.1321 & 12.4525 \\
\hline \multirow{2}{*}{$\begin{array}{l}\text { [Cd-L- } \\
\text { phenylalannate } \\
\text {-vitamin-C] }\end{array}$} & 5.37 & 8.172 & 10.60 & 12.6003 & 14.2803 & 18.9005 & 7.3228 & 11.1441 & 15.0728 & 17.7095 & 10.5243 & 12.8444 \\
\hline & 5.07 & 7.832 & 11.11 & & & & 7.1457 & 11.0387 & 14.9441 & 17.7098 & 10.5248 & 12.8451 \\
\hline \multirow{2}{*}{$\begin{array}{l}\text { [Cd-L-glutamate } \\
\text {-vitamin-C] }\end{array}$} & 5.56 & - & 10.65 & 13.4403 & - & 19.3205 & 7.5819 & - & 15.1529 & 19.6589 & - & 13.9847 \\
\hline & 5.24 & - & 11.33 & & & & 7.3853 & - & 15.0129 & 19.6592 & - & 13.9854 \\
\hline \multirow{2}{*}{$\begin{array}{l}\text { [Cd-L-aspartate - } \\
\text { vitamin- C] }\end{array}$} & 5.72 & 8.231 & 10.87 & 13.0203 & 13.8603 & 19.3205 & 7.8001 & 11.2243 & 15.4559 & 17.5174 & 8.8457 & 12.9680 \\
\hline & 5.41 & 7.901 & 9.82 & & & & 7.6249 & 11.1356 & 15.3261 & 17.5177 & 8.8463 & 12.9687 \\
\hline
\end{tabular}

\section{Conclusions}

In the present paper, interaction of $\mathrm{Cd}$ (II) between L-amino acids and vitamin- $\mathrm{C}$ in $\mathrm{pH}$ $7.30 \pm 0.01$ was investigated using simple DC polarography. The results indicated that current voltage curves were reversible and diffusion controlled in $1.0 \mathrm{M} \mathrm{KNO}_{3}$ at $\mathrm{pH}=7.30 \pm 0.01$ at $25^{\circ} \mathrm{C}$ and $35^{\circ} \mathrm{C}$.The stability constants varied from 2.23 to 11.33 which is quite reasonable values therefore, either L-amino acids alone or vitamin$\mathrm{C}$ or in combination or in the form of metal complex could be effective against $\mathrm{Cd}$ (II) toxicity and also be very much useful not only to control the aging process but also to prevent the HIV replication in vivo. The negative values of ?H indicated the exothermic nature of the metal-ligands interaction. The complexes were not stable at higher temperature which was confirmed by the values of $\mu \mathrm{G}$ and $\mu \mathrm{S}$ of complexes at higher temperature.

\section{Acknowledgement}

The authors are thankful to Head of the Department of Chemistry, Dr. H. S. Gour University, Sagar for providing the laboratory facilities.

Received 03 January 2008

Accepted 29 April 2008

\section{References}

[1] J. Brosnan, J. Nutr. 130 (2000) 988S.

[2] K. Pisarewicz, D. Mora, F. Pflueger, G. Fields, F. Marí, J. Am. Chem. Soc. 127 (2005) 6207.

[3] G. Wu, Y. Fang, S. Yang, J. Lupton, N. Turner, J. Nutr. 134 (2004) 489.

[4] M. W. Roomi, V. Ivanov, T. Kalinovsky, A. Niedzwiecki, M. Rath, J. Res. Commun Mol. Pathol. Pharmacol. (2004) 115.

[5] H. Martha, W. B. Stipanuk, Biochemical and physiological Aspects of Human Nutrition, Sounders Company, 2000. [6] M. Levine, S. C. Rumsey, Y. Wang, J. B. Park, R. Daruwala, Biochemical and Physiological Aspects of Human Nutrition, Philadelphia, W B Saunders, 2000, p. 541. 
[7] S. Fukuda, J. Curr. Med. Chem. 12 (2005) 2765;

[8] S. Harakeh, R. Jariwalla, AIDS Res. Hum. Retroviruses 13 (1997) 237.

[9] I. Sisseoff, J. Grisvard, E. Guille, Prog. Bio. Phys., Mol. Biol. 31 (1976) 165.

[10] J. A. Vale, T. J. Meredith, Poisoning Diagnosis and Treatment, 1981, p. 33.

[11] A. A. Khan, W. U. Malik, J. Indian Chem. Soc. 40 (1963) 565.

[12] F. Khan, Bull. Electrochem. 19 (2003) 283.

[13] S. N. Chadar, F. Khan, J. Indian Chem. Soc. 83 (2006) 1242.

[14] L. Meites, Polarographic Techniques, Interscience, New York, $2^{\text {nd }}$ edn., 1965, p. 131.

[15] P. L. Sahu, F. Khan, Ultra Sci. phys. Sci. 12 (2000) 106. [16] D. R. Crow, Polarography of metal complexes, Academic press, London, 1969.

[17] S. Chaberek, A. E. Martel, J. Am. Chem. Soc. 74 (1952) 5052.

[18] D. Deford, D. N. Hume, J. Am. Chem. Soc. 73 (1951) 5812.

[19] R. Dodke, F. Khan, Chem. Environ. Res. 1 (1992) 305.

[20] J. J. Lingane, Chem. Rev. 29 (1941) 1.

[21] W. B. Schaap, D. L. Mc Master, J. Am. Chem. Soc. 83 (1961) 4699.
[22] R. C. Kapoor, B. S. Agarawal, Principles of polarography, Wiley Eastern Ltd, New Delhi, 1991, p. 71.

[23] R. Dodke, F. Khan, J. Indian Chem. Soc. 70 (1993) 15.

[24] S. Vajhallya, F. Khan, Bull. Chem. Soc. (Japan) 72 (1999) 397.

[25] S. Vajhallya, F. Khan, J. Indian Chem. Soc. 76 (1999) 294.

[26] S. Vajhallya, F. Khan, Bull. Electrochem. 16 (2000) 311.

[27] A. E. Martell, M. Calvin, Chemistry of Metal Chelate Co mpounds, Prentice-Hall Inc., New York, $2^{\text {nd }}$ edn, 1952, p. 155 .

[28] B. V. Mrudula Rao, S. J. Swamy, P. Lingaish, Indian J. Chem. 24 (1985) 887.

[29] R. N. Allen, M. K. Shukla, J. Leszczynski, Int. J. Quant. Chem. 106(2006) 2366.

[30] B. L. Lewis, G. W. Luther III, H. Lane, T. M. Church, Electroanalysis, 7 (1995) 166.

[31] J. C. F. Rossotti, H. Rossotti, The Determination of Stability Constants, McGraw Hill Book Co., London, 1961.

[32] F. Khan, A. V. Mahajani, J. Indian Chem. Soc. 16 (1984) 165.

[33] F. Khan and A. Zaidi, J. Indian Council Chem. 16 (1999) 10. 